\title{
REGULATION OF THE ACTIVITIES OF JSC “RUSSIAN RAILWAYS”: EXPERT EVALUATION OF OPTIONS FOR IMPROVING
}

\author{
E.B. Kibalov, kibalovE@mail.ru \\ Institute of Economics and Industrial Engineering, Siberian Branch \\ of the Russian Academy of Sciences, Novosibirsk, Russian Federation
}

\begin{abstract}
The problem of the structural reform of railway transport in Russia is being considered in the article. Two ways of the reform are suggested, the methodology and results of the expert evaluation of the options are described in detail. There have been shown the experience dealing with the use of expert technology; in particular it has to do with the tools of the qualitative and quantitative estimation of the options by using the modified models of so-called Osgood's semantic differential which is widely used in the sociology. There are the questionnaires prepared for the examination; there are the results of the questionnaire of the expert group of qualified specialists of the Institute of Economics and industrial engineering of the Russian Academy of Sciences and the Siberian State Transport University. When finding a solution there have been used game theory methods, in particular, the theory of Nash equilibrium strategies, Wald's maximum criterion, Maximax, Hurwicz's, Savage's criterion. The results allow making several significant conclusions which suppose to encourage the optimal solution in the structural reform of railway transport in Russia.

Keywords: railways, reforms, operating costs, development prospects, alternatives, expected efficiency.
\end{abstract}

\section{Theory}

The state regulation of the activities of the natural monopolist JSC "Russian railways" is quite complex and it remains to be a problem with no solution. The issue has become an ambiguous one and the state regulation of the most important infrastructure system of the country has shown its flaws when the structural reform of railway transport fails [1], which was declared as a liberal one. Both the regulations of the operation and development of behavioral type using the tariff policy (mostly) and the structural regulations dealing with separation of the rolling stock (wagons and locomotive traction) from the railway system (rails and technological complex transportation process services ${ }^{1}$ ) are meant. One could not turn on competitive mechanisms of the activities of the monopolist and the vertical splitting of former Ministry of Transportation led to the appearance of the infrastructure monopolist with a mosaic organizational structure, which activities cannot be considered socially effective.

To clarify the theoretical moments of the problem we use the classic model of the game "prisoner's dilemma" (e.g., [2]). Suppose that the state government believes that the Federal Antimonopoly Service (FAS) is a player-controller and JSC "Russian railways" is a player-natural monopolist; so they do not work together, i.e. each of them has their own corporate interests, and they appear to be detrimental to the state. The first one sets too low tariffs and does not stabilize the work of the railway corporation; the second one increases costs too much and requires a tariff increase to cover them, which contributes to the budget deficit. It is necessary for the state with conditionally autonomous activities of the Federal Antimonopoly Service and JSC "Russian railways" to reach a compromise between the players. For this purpose, each of them gets a game numerical matrix that is developed by government experts; so each of them is supposed to evaluate options, ways of the governmental "railway" policy.

It has been proven [2] that the players acting rationally within the game when the agreement between them is excluded on the premise that it only can select the Nash optimal (equilibrium) solution, as for the Pareto solution which is the best for both players and for the state, it cannot be selected. Let us demonstrate this by means of the conventional numerical example.

Suppose that the regulator and the regulated in our model have the numerical matrix (Table 1).

\footnotetext{
${ }^{1}$ Stations, power supply, alerting systems, centralization, blocking, connection, transmission and processing of information, control of the movement of trains, buildings and equipment.
} 
Contingent revenue

\begin{tabular}{|l|l|c|c|}
\hline & & \multicolumn{2}{|c|}{ JSC “ Russian railways" } \\
\cline { 3 - 4 } & & Inflate the costs & Do not inflate the costs \\
\hline \multirow{2}{*}{$\sum_{4}$} & Tighten the regulation & $4 ; 4$ & $8 ; 0$ \\
\cline { 2 - 4 } & Liberalize the regulation & $0 ; 8$ & $7 ; 7$ \\
\hline
\end{tabular}

In Table 1 the billion figures denote the contingent revenue of the Federal Antimonopoly Service (and JSC "Russian railways") when choosing one or another cooperation strategy. It is clear that acting rationally but having only their own interests the players will choose the Nash optimal (equilibrium) solution which would give them 4 billion USD. That is if they act rationally they cannot win 7 billion USD in order to reach the optimum according to Pareto - which is better for both players and for the state, than the Nash equilibrium. This strategy has no balance; so in order to get 7 the Federal Antimonopoly Service should adopt the 2-nd strategy, but JSC "Russian railways" cannot adopt the 1-st one, thus, they win 0. Because of this JSC "Russian railways" is afraid to adopt the 2-nd strategy.

What should the state do for the players to work together? How to convince them to trust each other in order to reach the Pareto optimum? In our opinion there are two ways out.

\section{Ways to reform JSC "Russian railways"}

Option 1, proposed by JSC "Russian railways", - a long-term network contract between the government and the corporation. The option is not quite in the market nature, because it encourages the monopoly of the corporation as the only one carrier on a single network of the federal railways (Fig. 1), but if the contract is made in the right way from the legal and economic point of view, i.e. taking into account public and corporate interests and the uncertainty factor of future periods of its realization, then such institutional solution has a higher chance to be a Pareto optimal one.

Option 2 - is only a market one, when it is not considered that the monopoly of Russian railways is being natural, the corporation is split at least into three blocks with different management models (Fig. 1 and Fig. 2). As for the first two block, let us call them JSC " Russian railways "-1 и JSC " Russian railways "-2; they become vertically integrated (rolling stock plus rails) private railway companies competing on the railway network of the European Russia. As for the third block, we call it JSC "Russian railways" -3, it operates as a state-owned enterprise on railways of Asian Russia, where a tree structure configuration of the network The Trans-Siberian Railway does not allow to use competition as a means of improving the commercial viability of rail transport in the near future.

The logical result of the realization of option 2 should be the close-down of the ministry of transportation and the transfer of its functions to the new ministry of communication lines of Russia (Fig. 3), but not only due to the return to a traditional name. It seems that such decision would be the recognition of a higher competence of railway officials in the understanding of the unity of the transport complex of the country compared with officials of liberal activities - the ministry of transport of the Russian Federation that is responsible for the collapse of this system.

\section{Expert evaluation of the options}

The theoretical considerations and hypothetical options concerning further development of the railway reform required the experimental verification. It is known that in the economics full-scale experiments to indentify the effectiveness of theoretical hypotheses dealing with the improvement of its effectiveness are complex and inappropriate, although they are regularly conducted in Russia, to put it mildly, not always successfully. One way to avoid the negative effects of live experiments is preliminary modeling of relevant projects by all available means of the science and its fields at the moment. After that we show our experience of using expert technology, specifically tools of qualitative and quantitative evaluation of the options formulated above with the help of a modified model of so-called Osgood's semantic differential widely used in sociology [4].

The expert group was formed from the qualified specialists of the Institute of Economics and industrial engineering of the Russian Academy of Sciences and the Siberian State Transport University and there has been developed a questionnaire, which was filled in by each expert during the interview with 


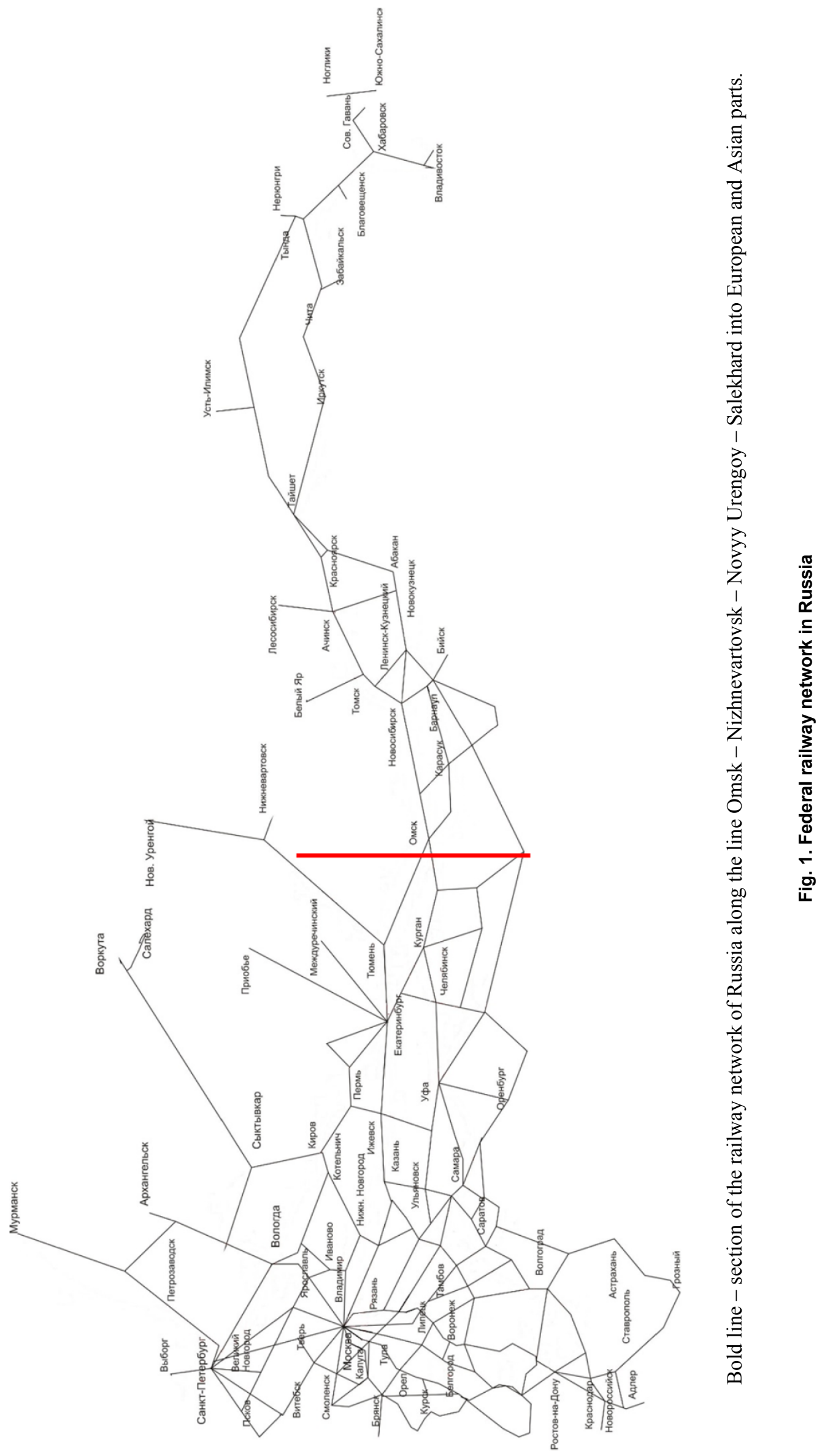




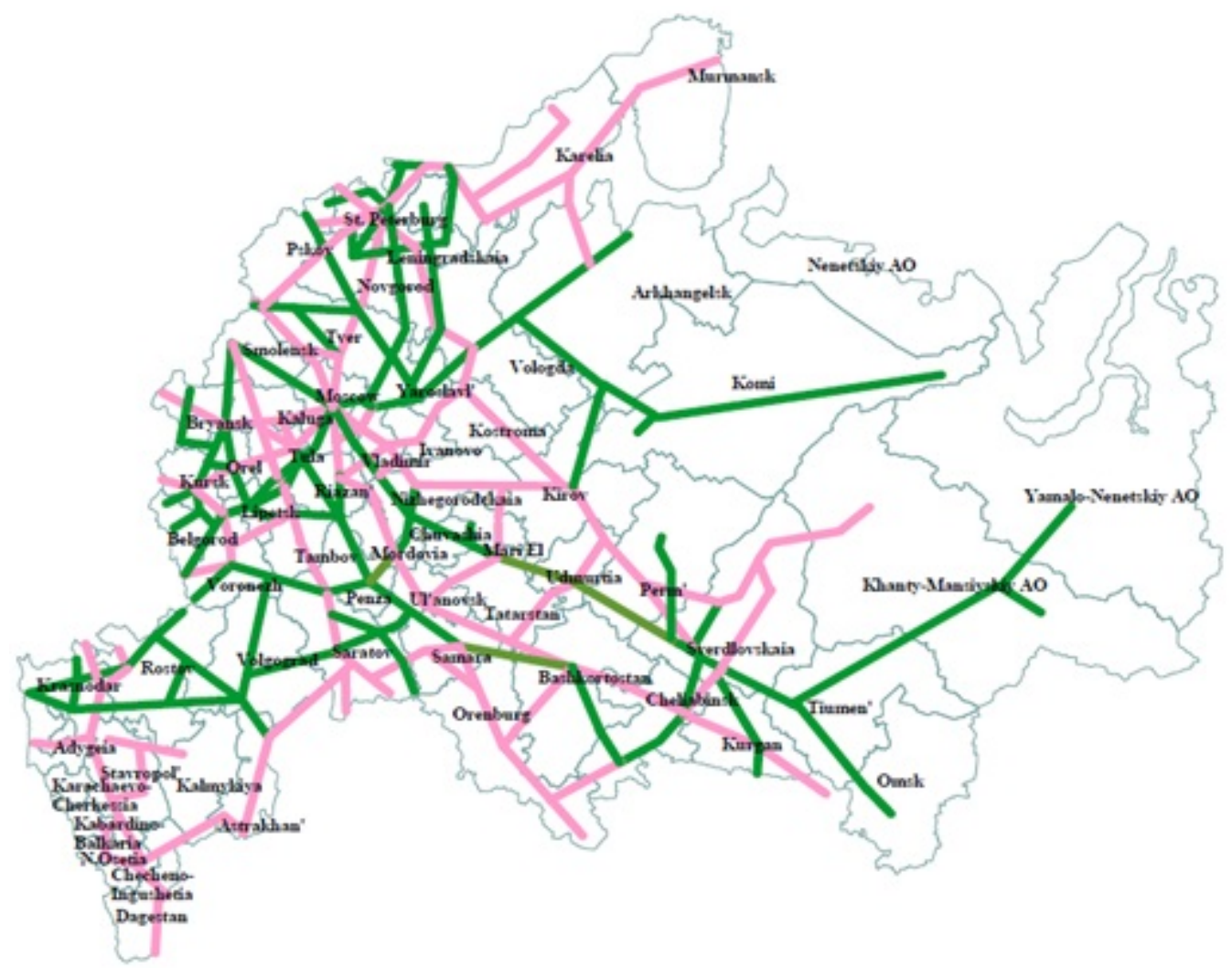

Fig. 2. JSC "Russian railways"-1 and JSC "Russian railways"-2: option dealing with the splitting of a single corporation [3]

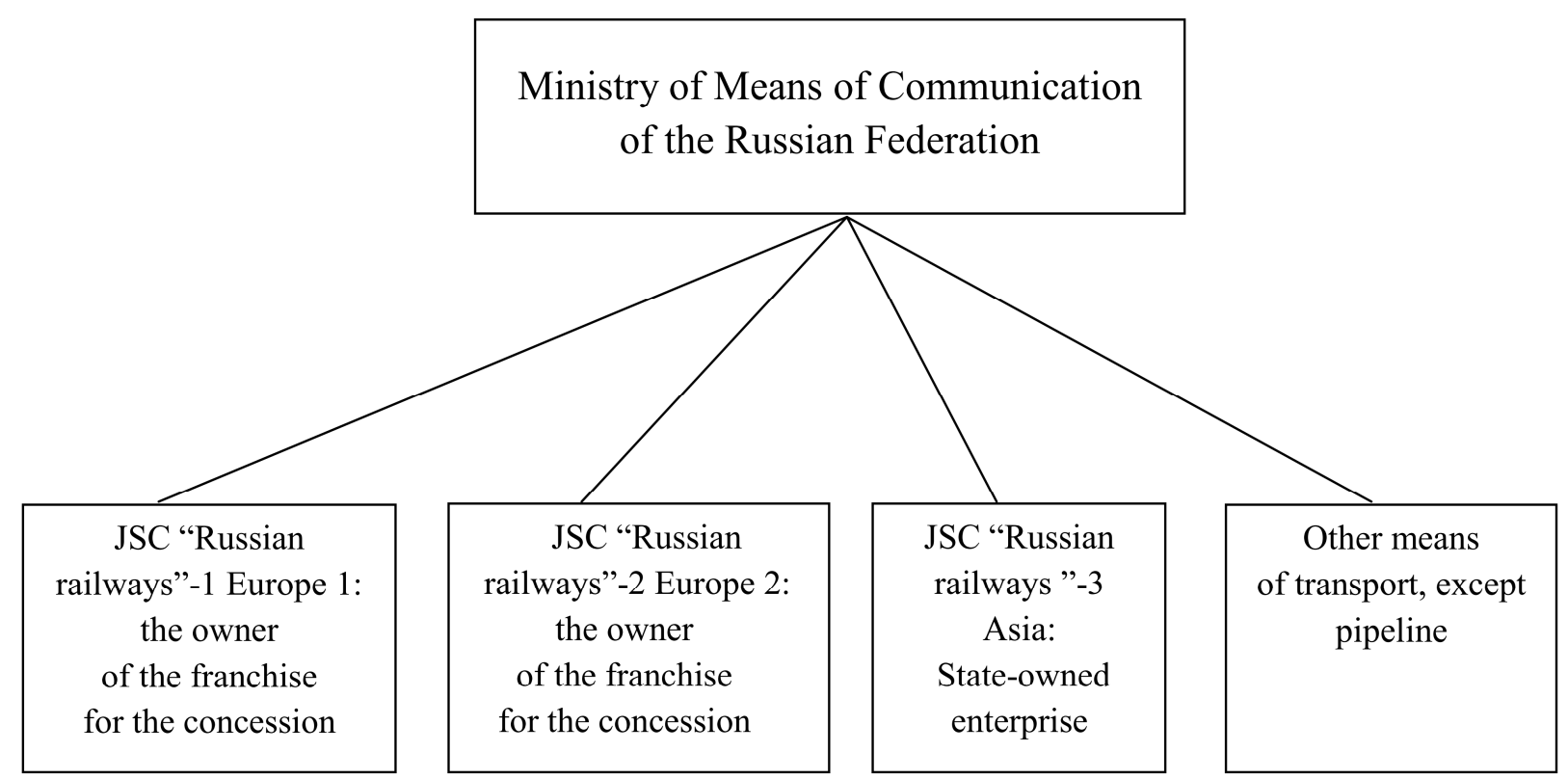

Fig. 3. The new ministry of railways as a regulator activity of JSC "Russian railways"-1, JSC "Russian railways"-2, JSC "Russian railways"-3 and other means of transport 


\section{Управление в социально-экономических системах}

a representative of the development team. Here below there are the questionnaires as certain tools of the expert analysis and synthesis which are filled in by all experts in front of the interviewer. The sign + in the relevant boxes at the intersections of lines and column denotes answers of one of the experts during personal interviews, and the figures in the column "priorities" denote the relative importance in the ordinal scale (according to experts' opinion) of problems the solution of which was initially presented as the purpose of the structural reform of the railway transport ${ }^{2}$. Thus, there were 7 questionnaires $^{3}$.

The data of the questionnaires with experts' opinions were analyzed by means of ORDEX and Excel in order to transfer results from the ordinal scale into the quantity one. The examination was carried out in three rounds. Concordance coefficients that describe the consistency of expert judgment [6] turned out to be too high in all evaluation procedures, so that one more examination was unnecessary.

In the first round the experts were proposed to fill in the questionnaire during the personal interview with the developer of this survey discussing the next development scenario of the economy in Russia.

Scenario 1: "Russia is a federal state with the dominant role of the Centre and socially oriented state regulation of the competitive economy".

In the second round it was proposed to carry out the similar assessment in this scenario.

Scenario 2: "Russia is a federal state with a coordinating and consultative role of the Centre and with the state regulation of the market that focused on the interests of big capital".

In the third round it was supposed that a different scenario was supposed to be realized.

Scenario 3: "Russia is a unitary state with a rigid vertical authority, provincial government and state capitalism".

At the end of the examination procedures and "digital conversion" of the questionnaires there was formed a numeric evaluation matrix (see Table 1) and using the criteria of the decision theory used for "discovering" some uncertainty in the game with "nature" there was identified the option chosen by the team of experts from alternatives of the development of the railway reform. Under "nature" that generates scenarios 1-3 the term "non-stationary economy" in Russia in the transition period was meant, when one or another scenario (of the external environment for evaluated alternatives) is hardly predictable.

To clarify the procedure of "digital conversion" of individual questionnaires that reflect the judgments of experts in Tables 2 and 3 there are answers of one of the experts as an example.

The assessment order of importance of alternatives (column "priorities" in Tables 2 and 3) and the expert evaluation were analyzed with ORDEX software that transfers ordinal assessment into a numerical scale, which according to the language of the system analysis means the determination of the coefficients of relative importance of the discussed problem. In this case (scenario 1) the vector of the coefficients of relative importance, which is the same for Tables 2 and 3, looks like:

$\{0.27 ; 0.45 ; 0.14 ; 0.14\}$,

reflecting (according to the experts) the fact that in Scenario 1 problems of the further development of the reform JSC "Russian railways" have the coefficients of relative importance that are put in curly brackets. To be precise: economic problem- 0.27 ; social problem -0.45 ; technical and technological problem -0.14 ; potential for the future -0.14 . These components of the vector of the coefficients of relative importance play the role of coefficients in the multidimensional function of subjective utility which is the criterion of comparative preference of options [7].

Then there were indentified subjective indicators of the degree of the positive (effectiveness) of options to deal with the problems in the context of each aspect and assuming that these aspects are equally important in all problems. Thus, in Table 2 there is only one sign "+" at the intersection of lines. The increase in public efficiency of railways and column "Very Positive" mean that the solution of the problem deserves 6 points in a seven-point scale and the aspect itself possesses the importance $(0.27 \cdot 0.5)$.

\section{Questionnaire for the expertise of the structural reform development of railway transport}

(The first round of the expertise, the scenario 1)

A question to the expert: How would you assess the impact of variant 1 of the structural reform development of railway transport in Russia on solving the following problems?

\footnotetext{
${ }^{2}$ http://rzd.ru/static/public/ru?STRUCTURE_ID=1314\&

${ }^{3}$ Specialists who had publications on this topic in local and international journals were taking part in this pilot examination on an anonymous basis. Based on an analysis of the procedures and the results of this examination there is an additional survey with an expanded list of closed questions of a questionnaire, an increased number of experts and modified tools.
} 
Table 2

\begin{tabular}{|c|c|c|c|c|c|c|c|c|c|}
\hline \multirow[t]{3}{*}{ 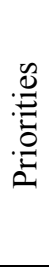 } & \multirow[t]{3}{*}{ Goals } & \multirow[t]{3}{*}{ Problems } & 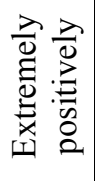 & 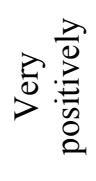 & 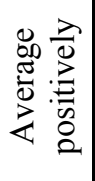 & 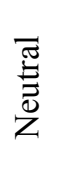 & 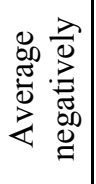 & 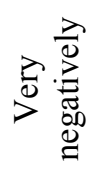 & 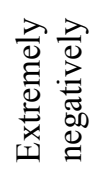 \\
\hline & & & \multicolumn{7}{|c|}{ Grades } \\
\hline & & & 7 & 6 & 5 & 4 & 3 & 2 & 1 \\
\hline \multirow[t]{2}{*}{2} & \multirow[t]{2}{*}{ Economic } & $\begin{array}{l}\text { 1. An Increase of public efficiency } \\
\text { of railways }\end{array}$ & & + & & & & & \\
\hline & & $\begin{array}{l}\text { 2. An increase of commercial effec- } \\
\text { tiveness of railways }\end{array}$ & & & + & & & & \\
\hline \multirow[t]{2}{*}{1} & \multirow[t]{2}{*}{ Social } & $\begin{array}{l}\text { 3. Creating conditions for staff motiva- } \\
\text { tion for effective work }\end{array}$ & + & & & & & & \\
\hline & & $\begin{array}{l}\text { 4. Creating conditions for management } \\
\text { motivation for effective work }\end{array}$ & & & + & & & & \\
\hline \multirow[t]{2}{*}{3} & \multirow[t]{2}{*}{ Technological } & $\begin{array}{l}\text { 5. An increase of the average speed of } \\
\text { passenger and freight transportation }\end{array}$ & & & + & & & & \\
\hline & & $\begin{array}{l}\text { 6. Improving the quality of transport } \\
\text { services (term, security, safety) }\end{array}$ & & + & & & & & \\
\hline \multirow[t]{2}{*}{3} & \multirow[t]{2}{*}{$\begin{array}{l}\text { Capacity } \\
\text { building } \\
\text { for the future }\end{array}$} & $\begin{array}{l}\text { 7. Sustainable development of the rail- } \\
\text { way infrastructure (investment policy) }\end{array}$ & + & & & & & & \\
\hline & & $\begin{array}{l}\text { 8. Ensuring the regular updating } \\
\text { the rolling stock and electronic logis- } \\
\text { tics support (investment policy) }\end{array}$ & + & & & & & & \\
\hline
\end{tabular}

A question to the expert: How would you assess the impact of variant 2 of the structural reform development of railway transport in Russia on solving the following problems?

Table 3

\begin{tabular}{|c|c|c|c|c|c|c|c|c|c|}
\hline \multirow[t]{3}{*}{$\frac{\mathscr{U}}{:}$} & \multirow[t]{3}{*}{ Goals } & \multirow[t]{3}{*}{ Problems } & 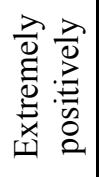 & 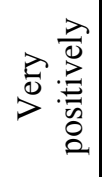 & 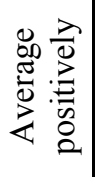 & $\begin{array}{l}\bar{\pi} \\
\stackrel{\Xi}{0} \\
\ddot{Z}\end{array}$ & 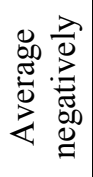 & 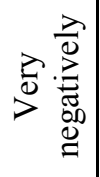 & 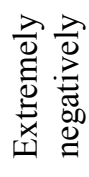 \\
\hline & & & \multicolumn{7}{|c|}{ Grades } \\
\hline & & & 7 & 6 & 5 & 4 & 3 & 2 & 1 \\
\hline \multirow[t]{2}{*}{2} & \multirow[t]{2}{*}{ Economic } & $\begin{array}{l}\text { 1. An Increase of public efficiency } \\
\text { of railways }\end{array}$ & & & + & & & & \\
\hline & & $\begin{array}{l}\text { 2. An increase of commercial effec- } \\
\text { tiveness of railways }\end{array}$ & + & & & & & & \\
\hline \multirow[t]{2}{*}{1} & \multirow[t]{2}{*}{ Social } & $\begin{array}{l}\text { 3. Creating conditions for staff motiva- } \\
\text { tion for effective work }\end{array}$ & & & + & & & & \\
\hline & & $\begin{array}{l}\text { 4. Creating conditions for management } \\
\text { motivation for effective work }\end{array}$ & & + & & & & & \\
\hline \multirow[t]{2}{*}{3} & \multirow[t]{2}{*}{ Technological } & $\begin{array}{l}\text { 5. An increase of the average speed of } \\
\text { passenger and freight transportation }\end{array}$ & & & + & & & & \\
\hline & & $\begin{array}{l}\text { 6. Improving the quality of transport } \\
\text { services (term, security, safety) }\end{array}$ & & + & & & & & \\
\hline \multirow[t]{2}{*}{3} & \multirow[t]{2}{*}{$\begin{array}{l}\text { Capacity } \\
\text { building } \\
\text { for the future }\end{array}$} & $\begin{array}{l}\text { 7. Sustainable development of the rail- } \\
\text { way infrastructure (investment policy) }\end{array}$ & & + & & & & & \\
\hline & & $\begin{array}{l}\text { 8. Ensuring the regular updating } \\
\text { the rolling stock and electronic logis- } \\
\text { tics support (investment policy) }\end{array}$ & & & + & & & & \\
\hline
\end{tabular}




\section{Управление в социально-экономических системах}

The same procedure is repeated at all columns and lines in the Tables 2 and 3, and then the number values of the function of subjective utility are formed, considered 2 compared variants by experts. In the example, they are as follows.

For variant 1 in scenario 1 :

$0,27 \cdot 0.5 \cdot 6+0.27 \cdot 0.5 \cdot 5+0.45 \cdot 0.5 \cdot 7+0.45 \cdot 0.5 \cdot 5+0.14 \cdot 0.5 \cdot 5+0.14 \cdot 0.5 \cdot 6+$

$+0.14 \cdot 0.5 \cdot 7+0.14 \cdot 0.5 \cdot 7=5.935$.

For variant 2 in scenario 2 :

$0.27 \cdot 0.5 \cdot 5+0.27 \cdot 0.5 \cdot 7+0.45 \cdot 0.5 \cdot 5+0.45 \cdot 0.5 \cdot 6+0.14 \cdot 0.5 \cdot 5+$

$+0.14 \cdot 0.5 \cdot 6+0.14 \cdot 0.5 \cdot 6+0.14 \cdot 0.5 \cdot 5=5.635$.

Therefore, according to the opinion of one of the experts, recorded in the questionnaire of the first round of expertise: variant lin scenario 1 is more preferable than variant $2(5.935>5.635)$.

However, seven experts participated in the expertise, and it was important to identify collective utility function of compared variants, and then using it to determine the most preferable variant in the scenarios, the probability of actualization of which was considered as unknown in the objective and subjective meanings. Fundamental uncertainty "was revealed" due to consolidation information of questionnaires in the elements of the strategic assessment matrix (Table 4). Elements (outcomes) contained the value of collective (ordinal) utility function of variants 1 and 2 in the scenarios $1-3$, and the preferable variant is identified using the criteria of decision theory (see e.g. [8]).

Scoring matrix

Table 4

\begin{tabular}{|c|c|c|c|}
\hline Scenarios & 1 & 2 & 3 \\
\hline 1 & 1 & 2 & 1 \\
\hline 2 & 2 & 1 & 2 \\
\hline
\end{tabular}

By Wald criterion (an utmost care), the most preferable variant is variant 1: a structural reform of developing railway transport in Russia in the case of the conclusion a contract between the state regulator and JSC "Russian railways".

By Maximax (a gambler), Savage and Hurwitz (at a level of pessimism $\alpha=0.66$ ) criteria, variants 1 and 2 are equally preferable.

By Bayesian and Laplace criteria, the analysis was not held on the premise: in the case of fundamental uncertainty these criteria are not adaptable.

\section{Conclusion}

1. The gradualist approach when the reform of critical infrastructure industry in the country is held quasi evolutionarily that means gradually and according to experts it is estimated positively.

2. However, such estimation can stay in the future only if the state regulator concludes agreements excluding the opportunistic behavior of the Contracting Parties with JSC "Russian Railways".

3. According to the analysis, compared variants are equally preferable by all other criteria (except Wald criterion) that is:

- variants and scenarios should be detailed while study with a view to enhancing their visibility for the experts;

- the category "unstructured" should be transferred to the category "small structured" i.e. the qualitative-quantitative;

- implementation of the first two paragraphs imply layer "reveal" of the source of fundamental uncertainty and its transferring to the category of probabilistic uncertainty;

- modern instrumentation system analysis (called neo system $[9,10])$ allows you to do this through an interdisciplinary approach based on expert knowledge in the field of economic, social, technical sciences and their synthesis on the basis of IT-technologies. 


\section{References}

1. Kibalov E.B. [The Failure of Railway Transport Reform: Through the Personalities]. Economics and Organisation, 2016, no. 5, pp. 44-54. (in Russ.)

2. Harsanyi J., Selten R. Obshchaya teoriya vybora ravnovesiya v igrakh [A General Theory of Equilibrium Selection in Games]. Moscow, Economic school, 2001. 405 p.

3. Guriev S., Pittman R., Shevyakhova E. Konkurentsia vmesto regulirovaniya: predlozheniya po restrukturizatsii zheleznodorozhnogo transporta na tret'em etape strukturnoi reform [Competition instead of Regulation: Offers on Restructuring of a Rail Transport at the Third Stage of Structural Reform]. Available at: http://fir.nes.ru/ sguriev/papers/railroad_rus.pdf.

4. Semanticheskiy metod Osguda [Semantic Method of Osgood]. Available at: http://www.studfiles.ru/ preview/5842812/.

5. Khutoretskiy A.B. Ekspertnoe otsenivanie ob'ektov po nekvantifitsirovannomu kriteriyu s pomoshch'yu modeli Berzha - Bruka - Burkova [Expert Estimation of Objects by Unquantifiable Criterion Using Berj - Brook - Burkov Model]. Novosibirsk, IEIE SB RAS, 1994. 130 p.

6. Metody ekspertnykh otsenok [Methods of expert estimates]. Available at: http://www.studfiles.ru/ preview/3515592/page:4/.

7. Keeney R.L., Raiffa H. Prinyatie resheniy pro mnogikh kriteriyakh: predpochteniya $i$ zameshcheniya [Decision-Making at Many Criteria: Preferences and Substitution]. Moscow, Radio and Communication Publ., 1981. 560 p.

8. Shubik M. [Game-Theoretic Solutions and Industrial Organization]. Mathematical Methods in the Social Sciences. Moscow, Progress Publ., 1973, pp. 170-195. (in Russ.)

9. Kornai Y. [Systemic Paradigm]. Questions of Economics, 2002, no. 4.

10. Kleiner G.B. Ekonomika institutsional'nykh sistem [Economics of Institutional Systems]. Moscow, Science Publ., 2004. 240 p.

Received 15 July 2016

\section{РЕГУЛИРОВАНИЕ ДЕЯТЕЛЬНОСТИ ОАО «РЖД»: ЭКСПЕРТНАЯ ОЦЕНКА ВАРИАНТОВ СОВЕРШЕНСТВОВАНИЯ}

\section{Е.Б. Кибалов}

Институт экономики и организации промышленного производства (ИЭОПП) СО РАН, 2. Новосибирск

Рассматривается проблема структурного реформирования железнодорожного транспорта России. Предлагается 2 варианта реформирования, подробно описывается методика и результаты экспертной оценки вариантов. Показан опыт использования экспертных технологий, конкретно, инструментов качественно-количественной оценки вариантов, с помощью модифицированной модели так называемого семантического дифференциала Ч. Осгуда, широко применяемой в социологии. Приведены опросные листы для проведения экспертизы, результаты анкетирования группы экспертов из состава квалифицированных специалистов Института экономики и организации промышленного производства (ИЭОПП) СО РАН и Сибирского государственного университета путей сообщения (СГУПС). При выборе решения использованы методы теории игр, в частности, теория равновесных стратегий Нэша, критерии Вальда (максимальной осторожности), максимакса (азартного игрока), Сэвиджа и Гурвица. Полученные результаты позволяют сделать ряд существенных выводов, которые должны способствовать выбору оптимального решения при структурном реформировании железнодорожного транспорта России.

Ключевые слова: железные дороги, реформирование, операчионные издержки, перспективы развития, альтернативы, ожидаемая эффективность. 


\section{Управление в социально-экономических системах}

Лumepamypa

1. Кибалов, Е.Б. Провал реформы железнодорожного транспорта: пройдемся по персоналиям / Е.Б. Кибалов // ЭКО. - 2016. - № 5. - С. 44-54.

2. Харшаньи, Дж. Общая теория выбора равновесия в играх / Дж. Харшаньи, Р. Зелтен; пер. с англ. под ред. Н.А. Зенкевича. - М.: Экономическая школа, 2001. - 405 c.

3. Гуриев, С. Конкуренщия вместо регулирования: предложения по реструктуризации железнодорожного транспорта на третьем этапе структурной реформы / С. Гуриев, Р. Питтман, E. Шевяхова. - http://fir.nes.ru/ sguriev/papers/railroad_rus.pdf.

4. Семантический метод Осгуда. - http://www.studfiles.ru/preview/5842812/.

5. Хутореиякий, А.Б. Экспертное оиенивание объектов по неквантифицированному критерию с помощью модели Бержа-Брука-Буркова: препринт / А.Б. Хуторечкий. - Новосибирск: ИЭОПП СО РАН, 1994. - 130 c.

6. Методы экспертных оиенок. - http://www.studfiles.ru/preview/3515592/page:4/.

7. Кини, Р.Л. Принятие решений при многих критериях: предпочтения и замещения / Р.Л. Кини, Х. Райфа; пер с англ. под ред. И.Ф. Шахнорва. - М.: Радио и связь, 1981. - 560 с.

8. Шубик, М. Теоретико-игровые решения и производственная организация / М. Шубик // Математические методы в сочиальных науках / под ред. П. Лазерсфельда и Н. Генри. - М.: Прогресс, 1973. - C. 170-195.

9. Корнай, Я. Системная парадигма / Я. Корнай // Вопросы экономики. - 2002. - № 4.

10. Клейнер, Г.Б. Экономика институциональных систем / Г.Б. Клейнер; ЦЭМИ РАН. - М.: Наука, 2004. - 240 c.

Кибалов Евгений Борисович, д-р экон. наук, профессор, главный научный сотрудник, Институт экономики и организации промышленного производства (ИЭОПП) СО РАН, г. Новосибирск; kibalovE@mail.ru.

Поступила в редакцию 15 июля 20162.

\section{ОБРАЗЕЦ ЦИТИРОВАНИЯ}

Kibalov, E.B. Regulation of the Activities of JSC "Russian Railways": Expert Evaluation of Options for Improving / Е.В. Kibalov // Вестник ЮУрГУ. Серия «Компьютерные технологии, управление, радиоэлектроника». - 2016. - Т. 16, № 4. - C. 64-72. DOI: $10.14529 /$ ctcr160407

\section{FOR CITATION}

Kibalov E.B. Regulation of the Activities of JSC "Russian Railways": Expert Evaluation of Options for Improving. Bulletin of the South Ural State University. Ser. Computer Technologies, Automatic Control, Radio Electronics, 2016, vol. 16, no. 4, pp. 64-72. DOI: $10.14529 /$ ctcr 160407 